\title{
PELAKSANAAN PENGADAAN BARANG/JASA MELALUI E-PROCUREMENT DI KABUPATEN BENER MERIAH PADA TAHUN 2020
}

\author{
Ziaulhak Umar, Suadi, Rasyidin \\ Prodi Magister Administrasi Publik, Fakultas Ilmu Sosial dan Ilmu Politik Universitas Malikussaleh \\ Jln. Tengku Chik diTiro, NO. 26, Lancang Garam, Lhokseumawe-24351 \\ Korespondensi: e-mail: suadi@unimal ac.id
}

\begin{abstract}
Penelitian ini mengkaji tentang implementasi kebijakan penyediaan barang/jasa secara elektronik melalui e-procurement di Kabupaten Bener Meriah Tahun 2020 yang dilaksanakan oleh Unit Kerja Pengadaan Barang dan Jasa (UKPBJ) yang masih mengalami permasalahan dalam penerapan $e$ procurement. Adapun permasalahan yang terjadi antara lain keterlambatan penyampaian informasi lelang yang mau di tenderkan, transparansi penyelenggaraan lelang dan penerimaan tender, serta adanya pengunduran pengumuman pemenang tender dari lelang barang dan jasa yang diselenggarakan. Tujuan penelitian adalah untuk menganalisis pelaksanaan pengadaan barang/jasa menggunakan e-procurement Perspektif teoritik menggunakan teori implementasi kebijakan dan implementasi pengadaan barang dan jasa. Metode Penelitian yang digunakan adalah metode penelitian kualitatif dengan teknik pengumpulan data melalui observasi, wawancara dan dokumentasi. Hasil penelitian menunjukkan bahwa pelaksanaan e-procurement belum maksimal dilaksanakan di UKPBJ Kabupaten Bener Meriah disebabkan oleh permasalahan komunikasi dan transparansi. Informasi yang tidak disajikan secara realtime memunculkan indikasi kurangnya keterbukaan informasi kepada publik yang berpengaruh pula pada transparansi pengadaan barang/jasa. Kapabilitas pelaksana juga masih belum maksimal disebabkan hanya 2 orang staf definitif di UKPBJ sedangkan yang lain merupakan staf yang diperbantukan dari SKPK lain dengan kualifikasi latar belakang pendidikan yang tidak sesuai. Interaksi antara UKPBJ dan pelaku usaha dilakukan secara terbatas dalam rangka mewujudkan tujuan penggunaan $e$ procurement. Nilai distribusi dan orientasi putusan disesuaikan dengan Peraturan Presiden Nomor 12 Tahun 2021 yang mengatur tentang penyediaan barang/jasa Pemerintah dan Standar Dokumen Pelayanan (SDP).
\end{abstract}

Keywords: Implementasi, Pengadaan Barang dan Jasa, E-procurement

\section{Pendahuluan}

Upaya pemerintah Indonesia dalam mencapai terciptanya good governance adalah dengan cara melakukan reformasi dalam segala kegiatan pemerintahan melayani publik dengan sistem elektronik yaitu e-government. Salah satu cara pemerintah demi mencapai pemerintahan yang baik adalah dengan melakukan perubahan dalam sistem penyediaan barang/jasa menggunakan pemanfaatan teknologi dan elektronik (e-procurement). Digunakannya e-procurement pada sistem pemerintahan merupakan bentuk perubahan demi mengurangi atau abahkan menghapus permasalahanpermasalahan yang selama ini terjadi dalam penyediaan barang/jasa menggunakan sistem manual.

Melalui penggunaan sistem elektronik pada penyediaan barang/jasa akan mengurangi interaksi secara langsung antar penyedia barang dan jasa bagi para panitia dengan demikian transparansi, dan efisiensi waktu serta biaya dalam penyediaan barang/jasa dapat terpenuhi, Sehingga penggunaan anggaran negara yang dipergunakan untuk penyediaan barang/jasa pemerintahan dapat di efektifkan. 
Dengan adanya E-procurement diharapkan potensi terjadinya kecurangan pada proses pengadaan barang dan jasa pemerintah dapat diminimalisir. E-procurement dapat meningkatkan efisiensi dan efikasi pada pengadaan barang dan jasa umum, mengurangi biaya, menaikkan kompetisi, untuk menjamin persamaan kesempatan dan perlakuan. Secara umum, tujuannya adalah menjamin integritas, kepercayaan masyarakat, dan transparansi dalam prosedur pengadaan barang/jasa umum). Sehingga dapat disimpulkan E-procurement dapat dipergunakan sebagai alat kontrol dalam suatu proses pengadaan barang dan jasa.

Penerapan e-procurement merupakan salah satu program nasional dalam rangka mewujudkan clean governance yaitu pemerintahan yang bersih dan terbebas dari korupsi, kolusi serta nepotisme. Dimana kedepannya seluruh instansi dapat menerapkan sistem penyediaan barang/jasa dengan menggunakan e-procurement. Penerapan e-procurement ini disosialisasikan di seluruh daerah di Indonesia pada tahun 2009. Pemerintah telah menginstruksikan seluruh kabupaten dan kota untuk menggunakan e-procurement pada tahun 2011 pada seluruh instansinya, termasuk dalam penyediaan barang/jasa di domain pemerintahan.

Pemerintah Kabupaten Bener Meriah sebagai salah satu Kabupaten yang ada di Provinsi Aceh, khususnya bagian penyediaan barang/jasa Sekretariat Daerah Kabupaten (Setdakab) Bener Meriah juga sudah menerapkan Sistem penyediaan barang/jasa secara elektronik (e-procurement) sebagai wujud menerapkan Peraturan Presiden Nomor 12 Tahun 2021 dengan harapan pelaksanaan penyediaan barang/jasa di Setdakab Bener Meriah dapat lebih efektif dan menghindari kecurangankecurangan yang mungkin dapat saja terjadi.

Penyediaan barang dan jasa secara elektronik sudah dijalankan di Setdakab Bener Meriah tahun 2011, dengan merujuk pada kebijakan sebelumnya yaitu Peraturan Presiden Nomor 54 Tahun 2010 Tentang Pengadaan Barang Dan Jasa Pemerintah yang saat ini sudah diperbaharui dengan Peraturan Presiden No.12 Tahun 2021. Setdakab Bener Meriah mulai menggunakan e-procurement ditandai pula dengan pembentukan bagian layanan pengadaan secara elektronik (LPSE) sebagai bagian yang menyediakan pengadaan barang dan jasa secara online.

Diterapkannya sistem e-procurement diharapkan akan menjadi solusi yang tepat untuk masalahmasalah yang terjadi pada proses pengadaan barang dan jasa pemerintah. E-procurement merupakan sistem yang memanfaatkan teknologi informasi yang didalamnya mengandung nilai-nilai transparansi, efisiensi, keterbukaan. Pada kenyataannya e-procurement masih memiliki kelemahankelemahan serta hambatan-hambatan dalam proses pelaksanaannya, seperti hasil observasi awal peneliti diketahui bahwa dalam menerapkan pengadaan barang/jasa menggunakan e-procurement di Kabupaten Bener Meriah terdapat permasalahan seperti keterlambatan penyampaian informasi lelang yang mau di tenderkan, transparansi penyelenggaraan lelang dan penerimaan tender, serta adanya pengunduran pengumuman pemenang tender dari lelang barang dan jasa yang diselenggarakan Setdakab Bener Meriah.

\section{Rumusan Masalah}

Berdasarkan uraian dari latar belakang penelitian maka rumusan masalah dalam penelitian ini yaitubagaimana pelaksanaan pengadaan barang/jasa melalui e-procurement di Kabupaten Bener Meriah pada tahun 2020?

\section{Kajian Terdahulu: Landasan Teoritis}

\section{Implementasi Kebijakan}

Implementasi kebijakan merupakan tahap yang vital dalam proses kebijakan publik, kebijakan yang berasal dari adanya program harus diterapkan dengan tujuan mendapatkan dampak sesuai dengan yang ditargetkan. Secara luas implementasi kebijakan diasumsikan sebagai tahapan dari sebuah proses pelaksanaan undang-undang yang telah disahkan yang didalamnya berbagai aktor, organisasi, prosedur, bekerjasama untuk menjalankan kebijakan dalam upaya untuk meraih tujuan- 
tujuan kebijakan atau program-program (Budi Winarno, 2014:147).

Van Horn dan Van Meter (Dalam Agustino Leo 2008:39) mendefenisikan implementasi sebagai tindakan-tindakan yang dilaksanakan oleh aparatur pemerintahan atau golongan-golongan yang berasal dari pemerintahan serta pihak swasta yang memiliki target untuk pencapaian tujuan dalam sebuah keputusan kebijaksanaan. Van Horn dan Van Meter membagi 4 indikator dalam implementasi kebijakan diantaranya:

1. Komunikasi

2. Sumber Daya

3. Disposisi

4. Struktur Birokrasi

5. Pengaruh Lingkungan Sosial, Ekonomi, dan Politik

Definisi kebijakan yang diimplementasikan mencakup pelaksanaan atau tindakan secara individu atau kelompok swasta serta publik yang secara langsung mecnapai sejumlah tujuan secara terus menerus dalam keputusan kebijakan yang telah ditetapkan sebelumnya. Hal ini meliputi usaha antar usaha mentransformasi keputusan ke dalam tindakan operasional, berusaha mencapai perubahan besar dan kecil sebagaimana yang dimandatkan oleh keputusan kebijakan atau program (Ekowati, 2009: 44).

\section{Pengadaan Barang/Jasa Melalui E-procurement}

Pengadaan barang dan jasa pemerintah adalah kegiatan dibidang pemerintahan yang paling rawan dengan korupsi (Kauffman, World Bank 2006). Sehingga kemudian pada tahun 2010 Presiden Indonesia mengatur secara tegas dalam Peraturan Presiden Nomor 54 Tahun 2010 bahwa Penyediaan barang dan jasa Pemerintah diwajibkan dilakukan secara elektronik atau e-procurement, yaitu Pemerintah Pusat, Provinsi, Kabupaten/ Kota wajib melakukan Penyediaan barang dan jasa secara elektronik (e-procurement).

E-procurementmerupakan aplikasi untuk pelaksanaan Penyediaan barang dan jasa secara elektronik dengan cara pemanfaatan teknologi informasi yang berbasis internet. Penyediaan barang dan jasa secara elektronik dilakukan dengan caratender atau seleksi. Berbagai macam pengertian $e$ procurementdari berbagai literatur, memiliki kesamaan makna yakni Penyediaan barang dan jasa dengan menggunakan teknologi informasi dan elektronik.

Sutedi (2012:254) mendefinisikan e-procurementsebagai sebuah sistem lelang dalam Penyediaan barang dan jasa pemerintah dengan memanfaatkan teknologi, informasi dan komunikasi berbasis internet agar dapat berlangsung secara efektif, efisien, terbuka dan akuntabel.

Sebelum tahun 2008, Penyediaan barang dan jasa pemerintahan dilakukan dengan menggunakan sistem konvensional. Sistem ini membutuhkan interaksi secara langsung dan tatap muka antara panitia Penyediaan dan penyedia jasa. Namun dalam proses Penyediaan barang dan jasa secara konvensional ditemukan berbagai penyimpangan. Penyimpangan tersebut sebagian besar pada proses pelaksanaan Penyediaan barang dan jasa.

Menurut Lembaga Kebijakan Pengadaan Barang dan Jasa Pemerintah (2010) adanya permasalahan yang disebabkan tidak transparannya pengumuman, pengaturan tender, menyalahi prosedur dalam proses penyediaan, terjadinya intervensi terhadap panitia pelaksana, spesifikasi atau syarat-syarat dokumen Penyediaan yang diarahkan untuk pihak tertentu serta tidak fokusnya panitia dalam melaksanakan tugas dikarenakan tugas ganda/sampingan. Berbagai penyimpangan tersebut bersifat administratif dan berkaitan dengan anggaran, seperti korupsi, kolusi dan mark up anggaran yang pada akhirnya merugikan keuangan negara maupun daerah.

Penyediaan secara konvensional juga membutuhkan waktu yang relative lebih lama, sehingga dianggap menguras biaya serta waktu, informasi yang tidak akurat mengakibatkan persaingan yang tidak sehat kepada para penyedia barang dan jasa yang kemudian mempengaruhi kualitas penyediaan barang dan jasa, ekslusi yang terjadi kepada penyedia potensial dan pemberian keistimewaan kepada penyedia tertentu.

Menurut Purwanto dkk (2012) permasalahan yang terjadi selama ini dalam penyediaan barang dan jasa secara manual antara lain sebagai berikut:

a) minimnya monitoring; 
b) penyalahgunaan wewenang;

c) penyimpangan kontrak;

d) kolusi antara pejabat publik dan rekanan;

e) manipulasi dan tidak transparan;

f) kelemahan SDM.

Penyediaan barang dan jasa dalam Peraturan Presiden Republik Indonesia Nomor 70 Tahun 2012 adalah kegiatan untuk mendapatkan barang dan jasa oleh Kementerian/Lembaga/Satuan Kerja Perangkat Daerah/Institusi yang prosesnya dimulai dari perencanaan kebutuhan sampai diselesaikannya seluruh kegiatan untuk memperoleh barang dan jasa.

Penyediaan secara elektronik atau e-procurement adalah Penyediaan barang dan jasa yang dilaksanakan dengan menggunakan teknologi informasi dan transaksi elektronik yang merujuk pada kebijakan dan peraturan perundang-undangan. Andrianto (2007: 215) menejlaskaneprocurementadalah kegiatan Penyediaan barang dan jasa yang dilakukan dengan tahapan lelang secara elektronik.

Sedangkan menurut Christhoper \& Schooner (2007), e-procurementyaitu sebuah kegiatan untuk memperoleh barang dan jasa secara transparan, efektif dan efisien sesuai dengan kebutuhan dan keinginan penggunanya. Abidin (2012) menyatakan e-procurement merupakan Penyediaan barang dan jasa yang dilaksanakan dengan menggunakan teknologi informasi dan transaksi elektronik sesuai dengan ketentuan perundangundangan.

Kalakota (2001) menjelaskan e-procurement merupakan proses Penyediaan barang atau lelang dengan memanfaatkan teknologi informasi dalam bentuk website. Electronic procurement (eprocurement) adalah integrasi antara Penyediaan elektronik dan pengelolaan semua kegiatan Penyediaan termasuk permohonan pembelian, otorisasi, pemesanan, pengiriman dan pembayaran antara pembeli dan pemasok (Chaffey, 2007).

Pelaksanaan e-procurement termasuk ke dalam salah satu program nasional dalam rangka menciptakan clean governance di Indonesia, menjadi negara yang bebas dari segala bentuk korupsi. Dimana nantinya melalui program tersebut seluruh instansi pemerintah baik pusat maupun daerah harus menerapkan e-procurement dalam Penyediaan barang dan jasa. Penerapan e-procurement ini disosialisasikan di seluruh daerah di Indonesia pada tahun 2009.

Disebutkan dalam artian lain e-procurementadalah: "kegiatan pembelian barang dan jasa yang diperlukan bagi kebutuhan operasional organisasi secara elektronik" menurut Oliviera (2001:43).

Menurut Helle Zinner dan Kim Viborg (2003: 1) menyatakan bahwa e-procurement pada lembaga pemerintahan terdapat empat perspektif diantaranya kapabilitas, interaktif, nilai distribusi, dan berorientasi pada keputusan. Tujuan dari empat perspektif tersebut adalah menciptakan efektivitas dan efisiensi dari pelaksanaan pengadaan barang dan jasa secara elektronik melalui $e$ procurement.

\section{Metodologi Penelitian}

Penelitian ini menggunakan penelitian kualitatif dengan pendekatan deskriptif analisis, karena persoalannya sangat komprehensif, mendalam dan sangat luas. Pengumpulan data dilakukan dengan observasi, wawancara dan dokumentasi.

\section{Hasil Penelitian}

Penelitian ini menggunakan penelitian kualitatif dengan pendekatan deskriptif analisis, karena persoalannya sangat komprehensif, mendalam dan sangat luas. Pengumpulan data dilakukan dengan observasi, wawancara dan dokumentasi.

\section{Hasil Penelitian}


Kebijakan pengadaan barang/jasa secara elektronik melalui e-procurement di Setdakab Bener Meriah mulai diterapkan semenjak tahun 2013 melalui Peraturan Presiden Nomor 16 Tahun 2018 yang mengatur tentang pengadaan barang/jasa pemerintah, peraturan tersebut saat ini telah diperbaharui menjadi Peraturan Presiden Nomor 12 Tahun 2021 yang mengatur tentang penyediaan barang/jasa Pemerintah perubahan atas Peraturan Presiden Nomor 16 Tahun 2018.

Pelaksanaan pengadaan barang/jasa melalui e-procurement di Kabupaten Bener Meriah pada tahun 2020 masih mengalami beberapa permasalahan sehingga belum mencapai transparansi, efektif dan efisiensi serta keterbukaan sebagaimana harapan dari dilaksanakannya e-procurement dalam pengadaan barang/jasa. Adapun yang menyebabkan hal tersebut diantaranya:

1. Keterlambatan penyampaian informasi lelang untuk tender pengadaan barang/jasa.

2. Transparansi penyelenggaraan lelang dan penerimaan tender.

Pengunduran pengumuman pemenang tender dari lelang barang/jasa yang diselenggarakan oleh UKPBJ

Terdapat 21 paket yang mengalami keterlambatan dalam pelaksanaan pelelangan dan mempengaruhi pengerjaan paket lelangnya, ke-21 paket tersebut mengalami keterlambatan pelelangan disebabkan adanya kesalahan teknis pada SKPK terkait. Dasar pelaksanaan pengadaan barang dan jasa menggunakan sistem elektronik e-procurement di Kabupaten Bener Meriah adalah mengikuti Perpres Nomor 16 tahun 2018 dan dari 2013 dilaksanakan sampai tahun 2020 sudah berlangsung selama tujuh tahun dan sudah mulai menunjukkan pelaksanaan penggunaan $e$ procurement yang efektif dan transparan.

Namun hal tersebut berbeda dengan hasil observasi peneliti yang menunjukkan bahwa dalam pengadaan barang/jasa menggunakan e-procurement di UKPBJ Kabupaten Bener Meriah masih belum dilakukan secara efektif dari segi penggunaan program oleh para sumber daya manusia di UKPBJ.

Adanya keluhan dari para pelaku usaha di Kabupaten Bener Meriah mengenai tertutupnya informasi kapan lelang diadakan untuk dapat diikuti, kemudian bagaimana tata cara mengikuti lelang, bahkan sampai kepada tertutupnya informasi mengenai pemenang tender dalam pengadaan barang/jasa di UKPBJ Kabupaten Bener Meriah.

Hal tersebut menunjukkan bahwa pihak UKPBJ belum menerapkan tujuan utama dari penggunaan e-procurement seperti yang disampaikan oleh Willem (2012) tujuan penggunaan $e$ procurement antara lain:

1. Meningkatkan transparansi dan akuntabilitas

2. Meningkatkan akses pasar dan persaingan usaha

3. Meningkatkan tingkat efisiensi proses pengadaan

4. Mendukung proses monitoring dan audit

5. Memenuhi kebutuhan akses informasi terkini

Pada hakikatnya transformasi pengadaan barang dan jasa dari manual kepada sistem elektronik adalah untuk menghindari terjadinya penyelewengan pengadaan barang/jasa di pemerintahan yang selama ini sarat dengan $\mathrm{KKN}$, sehingga melalui penggunaan e-procurement dalam pengadaan barang/jasa seharusnya informasi-informasi dapat disampaikan secara transparan kepada pelaku usaha karena dengan demikian dapat meningkatkan akses pasar dan persaingan usaha yang sehat.

Pengadaan barang/jasa harus dapat memenuhi prinsip-prinsip dalam pelaksanaannya yaitu efektif, efisien, kompetitif, transparan dan bertanggung jawab. Pada UKPBJ Kabupaten Bener Meriah penggunaan sistem e-procurement pengadaan barang/jasa, masih belum efektif. efisiensi penggunaan e-procurement, transparansi dan kompetitif penyelenggaraannya belum dapat dilaksanakan secara maksimal karena belum sepenuhnya mencapai sasaran dan target sebagaimana harapan.

segala informasi dianggap oleh para informan sudah disampaikan melalui halaman website http://lpse.benermeriahkab.go.id yang telah tertera didalamnya mengenai segala jenis informasi pengadaan barang/jasa meliputi jadwal lelang, pemenang lelang, paket-paket yang dilelang, sehingga menurut para pelaksana e-procurement di UKPBJ Kabupaten Bener Meriah mereka sudah melaksanakan pengadaan barang/jasa secara transparan.

Meskipun pengadaan barang/jasa dianggap sudah transparan karena sudah menampilkan semua 
hal didalam halaman website, namun menurut hasil penelitian yang telah dilakukan oleh Arsyam, dkk (2016: 1) menunjukkan bahwa e-procurement meskipun sudah menggunakan sistem elektronik masih juga belum transparan hal tersebut disebabkan belum adanya transparansi mengenai penetapan calon penyedia pada proses pembukaan penawaran karena pada proses ini yang dapat melihat hanyalah panitia dan pemilik penawaran, sedangkan masyarakat ataupun pihak-pihak lainnya tidak dapat melihatnya.

Menurut Burkens transparansi (keterbukaan) memberikan makna bahwa dalam banyak bidang kegiatan pemerintah, masyarakat ikut serta langsung dalam proses persiapan, kebijaksanaan dan pembentukan keputusan. Transparansi pemerintahan memungkinkan peran serta masyarakat dalam pengembilan keputusan.Peran serta merupakan bentuk jaminan bagi warga masyarakat atau pihak yang ada pada umumnya juga dapat mengajukan keberatan melawan keputusan hjika itu tidak setuju (Thamrin, 2013).

alah satu hal yang penting dalam penyelenggaraan pengadaan barang dan jasa ialah masalah transparansi. Transparansi dan akuntabilitas dalam penyusunan anggaran, penetapan anggaran, perubahan anggaran dan perhitungan anggaran merupakan wujud pertanggungjawaban pemerintah daerah kepada masyarakat, maka dalam proses pengembangan wacana publik di daerah sebagai salah satu instrumen kontrol pengelolaan anggaran daerah, perlu diberikan keleluasaan masyarakat untuk mengakses informasi tentang kinerja dan akuntabilitas anggaran.

Pihak UKPBJ menganggap mereka sudah secara transparan dalam penyampaian informasi, dan sudah maksimal dalam menerapkan e-procurement di Kabupaten Bener Meriah, hanya saja pelaksanaan tersebut belum mampu mencapai transparansi bagi para pelaku usaha, karena mereka menganggap pemberian informasi di website saja tidak cukup, melainkan harus juga dapat disosialisasikan secara aktif kepada semua pihak, serta dalam halaman website informasi yang diberikan hanya hal-hal umum, tetapi secara merinci tidak disediakan di halaman website tersebut.

Pelaksanaan pengadaan barang/jasa di Kabupaten Bener Meriah oleh UKPBJ dapat disimpulkan bahwa pelaksanaan pengadaan barang/jasa menggunakan e-procurement yang sudah dijalankan selama 7 tahun masih mengalami permasalahan pada penyampaian informasi secara akurat. Informasi mengenai pendaftaran, paket-paket yang dilelang, persyaratan dan informasi dianggap telah disampaikan pada website LPSE, namun pelaku usaha menganggap informasi yang diberikan tidak rinci, ketika ada perubahan-perubahan syarat, waktu dan lainnya tidak disampaikan ulang pada website sehingga sering sekali pelaku usaha tidak mendapatkan informasi lanjutan mengenai perubahan-perubahan tersebut.

Dalam proses implementasi, pengadaan barang/jasa yang bersifat tender dilakukan dengan cara pelelangan atau tawaran kepada semua pihak yang memenuhi syarat tender. Impelemtasi $e$ procurement dalam pengadaan barang/jasa di UKPBJ Kabupaten Bener Meriah pada dasarnya sudah menunjukkan transparansi, hal ini ditunjukkan melalui penggunaan elektronik, informasi berkaitan dengan proses pengadaan barang/jasa dapat diperoleh secara terbuka dan mudah oleh pihak yang berkepentingan, yaitu ULP, LPSE, auditor, PPK (Pejabat Pembuat Komitmen) dan masyarakat atau kalangan umum.Upaya yang dilakukan oleh UKPBJ dalam mengimplementasikan e-procurement dalam mewujudkan transparansi adalah dengan meningkatkan persaingan usaha yang sehat dengan e-procurement mengikuti Sistem Pengadaan Secara Elektronik (SPSE) yang diciptakan oleh Pemerintah Pusat agar tidak terjadi persekongkolan dan mempengaruhi panitia pengadaan barang/jasa.

Namun, diketahui bahwa masih belum maksimalnya pencapaian tujuan terutama dalam meningkatkan peluang persaingan usaha yang sehat diantara para peserta tender, karena melalui penyampaian informasi yang tidak akurat dan seringnya terjadi perubahan-perubahan informasi yang tidak di follow up kepada pelaku usaha, menjadikan hanya orang-orang tertentu yang terkadang dapat cepat tanggap melengkapi berkas persyaratan, serta mengejar ketertinggalan waktu untuk mengikuti lelang.

Implementasi kebijakan pengadaan barang/jasa secara elektronik melalui e-procurement di UKPBJ Kabupaten Bener Meriah secara langsung melalui perwujudan transparansi pelayanan publik juga secara langsung mendukung proses monitoring dan audit adalah hampir dapat tercapai secara maksimal.

Hal ini diketahui dari semua data mengenai pengadaan barang/jasa atau biasa disebut lelang, 
akan tersimpan langsung ke Sistem Pengadaan/penyediaan Barang/Jasa (SPSE) dan website, sehingga memudahkan KPK, BPK, Lembaga Kebijakan Pengadaan Barang/jasa Pemerintah (LKPP), BPKP dan Inspektorat untuk pemeriksaan dan pengawasanpengadaan barang/jasa atau lelang.

Implementasi kebijakan pengadaan barang/jasa secara elektronik melalui e-procurement di UKPBJ merupakan bentuk desentralisasi dalam pemerintahan. Penggunaan kewenangan secara politis yang dipraktekkan dalam rangka mengontrol dan mengelola sumberdaya sebesar-besarnya untuk kepentingan masyarakat atau warganya melalui proses pembangunan ekonomi maupun sosial, maka pemerintah diberikan kewenangan untuk mengatur kepengurusan, proses pembuatan keputusan perumusan kebijakan, kapasitas implementasi, pengaliran informasi, aktivitas kepemimpinan serta upaya-upaya penertiban kehidupan berbangsa dan bernegara.

Implementasi kebijakan pengadaan barang/jasa menggunakan sistem elektronik melalui $e$ procurement di UKPBJ Kabupaten Bener Meriah adalah wujud dari pelaksanaan good governance ditingkat pemerintahan daerah dengan tujuan tercapainya transparansi publik dan akuntabilitas kepada publik sehingga pada akhirnya mampu memberikan pelayanan publik yang efektif dan efisien.

Sesuai dengan Peraturan Presiden Nomor 12 Tahun 2021 Pemerintah dinyatakan bahwa pengadaan barang/jasa oleh UKPBJ mempunyai peran penting untuk memberikan peningkatan pelayanan kepada masyarakat serta menunjang pembangunan daerah. Dalam mewujudkan pengadaan barang/jasa yang bermanfaat maka UKBPJ Kabupaten Bener Meriah perlu melakukan pengaturan pengadaan barang/jasa yang memberikan pemenuhan nilai dan manfaat yang sebesar-besarnya (value for money) dan kontribusi dalam peningkatan penggunaan produk dalam negeri, peningkatan usaha $\mathrm{kecil} / \mathrm{mikro}$, serta usaha menengah bagi para pelaku-pelaku usaha,serta pembangunan berkelanjutan bagi Kabupaten Bener Meriah.

Menurut Helle Zinner dan Kim Viborg (2003: 1) menyatakan bahwa e-procurement pada lembaga pemerintahan terdapat empat perspektif diantaranya kapabilitas, interaktif, nilai distribusi, dan berorientasi pada keputusan. Tujuan dari empat perspektif tersebut adalah menciptakan efektivitas dan efisiensi dari pelaksanaan pengadaan barang dan jasa secara elektronik melalui $e$ procurement.

Kapabilitas para pelaksana e-procurement dalam pengadaan barang/jasa di UKPBJ Kabupaten Bener Meriah belum maksimal karena ada beberapa staf yang berada di UKPBJ merupakan staf/pegawai bantuan dari bidang lain, yang bukan secara khusus ditempatkan di UKPBJ untuk menangani dan melaksanakan e-procurement, sehingga pelaksanaan e-procurement belum efektif, efisien disebabkan pula oleh kapabilitas para pelaksana, meskipun diketahui para sumberdaya manusia yang ditempatkan di UKPBJ wajib memiliki sertifikat pengelola pengadaan barang dan jasa, sehingga tetap diharapkan mampu melaksanakan e-procurement sesuai dengan tugas, pokok dan fungsinya.

Berdasarkan hasil observasi dan wawancara pada indikator interaktif dapat dipahami bahwa para pelaksana e-procurement membatasi interaksi dengan para pelaku usaha dan hanya fokus memberikan informasi melalui halaman website LPSE, namun terkadang informasi yang diberikan kurang rinci dan menimbulkan ketidakjelasan makna, sehingga tetap saja para pelaku usaha yang tidak memahaminya perlu menanyakan maksud lebih lanjut, namun interaksi hanya dapat dilakukan melalui media telepon ataupun media whatsapp di smartphone.

Indikator selanjutnya adalah nilai distribusi. Nilai distribusi dalam pelaksanaan pengadaan barang/jasa melalui e-procurement disebutkan dalam Peraturan Presiden Nomor 12 Tahun 2021 yang mengatur tentang penyediaan barang/jasa Pemerintah perubahan atas Peraturan Presiden Nomor 16 Tahun 2018 meliputi harga perkiraan sendiri (HPS) yaitu perkiraan harga barang/jasa yang ditetapkan oleh PPK yang telah memperhitungkan biaya tidak langsung, keuntungan dan PPN, kemudian pengadaan langsung barang/pekerjaan konstruksi/jasa lainnya adalah metode pemilihan untuk mendapatkan penyedia barang/pekerjaan konstruksi/jasa lainnya yang bernitai paling banyak $\mathrm{Rp}$ 200.000.000,00 (dua ratus juta rupiah). Serta pengadaan langsung jasa konsultansi adalah rnetode pemilihan untuk mendapatkan penyedia jasa konsultansi yang bernilai paling banyak $\mathrm{Rp}$ 100.000.000,00 (seratus juta rupiah).

Indikator terakhir dalam implementasi pengadaan barang dan jasa menggunakan $e$ procurement adalah orientasi pada keputusan. Orientasi pada keputusan dalam pengadaan barang dan jasa mengacu kepada ketentuan Perpres dan SDP sama halnya dalam menentukan harga distribusi, 
orientasi pada keputusan untuk menentukan pemenang tender mengacu kepada pedoman-pedoman tersebut.

Implementasi kebijakan pengadaan barang/jasa pada akhirnya diharapkan dapat mencapai transparansi dan akuntabilitas publik sebagaimana harapan dilaksanakannya e-procurement pada sistem pengadaan barang dan jasa pada pemerintahan dengan memperhatikan kapabilitas pelaksana, interaktif antar pelaksana dengan pihak terkait, penentuan nilai distributif sesuai peraturan yang berlaku, serta berorientasi pada kebijakan yang telah ditetapkan.

\section{Kesimpulan}

Berdasarakan hasil penelitian tersebut di atas, maka dapat disimpulkan sebagai berikut:

1. Pelaksanaan pengadaan barang/jasa melalui e-procurement di UKPBJ Kabupaten Bener Meriah mulai diterapkan sejak tahun 2013. Namun pada pelaksanaannya masih mengalami beberapa persoalan seperti keterlambatan penyampaian informasi lelang untuk tender pengadaan barang/jasa, transparansi penyelenggaraan lelang dan penerimaan tender, serta pengunduran pengumuman pemenang tender dari lelang barang/jasa yang diselenggarakan oleh UKPBJ tanpa memberitahukan kepada peserta lelang/tender.

a. Kapabilitas para pelaksana e-procurement dalam pengadaan barang/jasa di UKPBJ Kabupaten Bener Meriah belum maksimal karena ada beberapa staf yang berada di UKPBJ merupakan staf/pegawai bantuan dari bidang lain, yang bukan secara khusus ditempatkan di UKPBJ untuk menangani dan melaksanakan e-procurement

b. Interaktif, interaksi antara pelaksana dengan pelaku usaha semakin terbatas, karena inilah harapan daripada transformasi pengadaan barang/jasa dari sistem manual kepada sistem elektronik. Namun keterbatasan interaksi antara pelaksana dan pelaku usaha dimana informasi apapun mengenai pengelolaan barang dan jasa disampaikan pada halaman website LPSE menyebabkan sering terjadinya miss communication dan keterbatasan interaktif menjadikan permasalahan baru dalam hal transparansi dan keterbukaan informasi kepada publik.

c. Nilai Distribusi dalam pelaksanaan pengadaan barang/jasa melalui e-procurement disebutkan dalam Peraturan Presiden Nomor 12 Tahun 2021 yang mengatur tentang penyediaan barang/jasa Pemerintah perubahan atas Peraturan Presiden Nomor 16 Tahun 2018 meliputi harga perkiraan sendiri (HPS) yaitu perkiraan harga barang/jasa yang ditetapkan oleh PPK yang telah memperhitungkan biaya tidak langsung, keuntungan dan PPN

d. Orientasi Pada Keputusan dalam pengadaan barang dan jasa mengacu kepada ketentuan Perpres dan SDP sama halnya dalam menentukan harga distribusi, orientasi pada keputusan untuk menentukan pemenang tender mengacu kepada pedoman-pedoman tersebut.

\section{Daftar Pustaka}

Peraturan Lembaga Kebijakan Pengadaan Barang/Jasa Pemerintah (LKPP) Nomor 11 Tahun 2018 Tentang Katalog Elektronik

Peraturan Lembaga Kebijakan Pengadaan Barang/Jasa Pemerintah (LKPP) Nomor 7 Tahun 2020 yang merupakan Perubahan Atas Perlem LKPP Nomor 11 Tahun 2018 Tentang Katalog Elektronik

Peraturan Presiden No. 54 Tahun 2010 Tentang Pengadaan Barang/Jasa Pemerintah

Peraturan Presiden Nomor 12 Tahun 2021 Tentang Pengadaan Barang dan Jasa Pemerintah

Peraturan Presiden Nomor 16 Tahun 2018 Tentang Pengadaan Barang dan Jasa Pemerintah

Peraturan Presiden RI Nomor 70 Tahun 2012 Tentang Pengadaan Barang dan Jasa

Winarno, B. 2014. Kebijakan Publik: Teori, Proses, dan Studi Kasus; Yogyakarta: Center of Academic Publishing Service (CAPS).

Ekowati, L, Roro, M. 2009. Perencanaan, Implementasi dan Evaluasi Kebijakan atau Program. Surakarta: Pustaka Cakra. 
